\title{
Traditional Food Items in Ogimi, Okinawa: L-Serine Content and the Potential for Neuroprotection
}

\author{
Paul Alan $\operatorname{Cox}^{1} \cdot$ James S. Metcalf $^{1}$
}

Published online: 7 February 2017

(C) The Author(s) 2017. This article is published with open access at Springerlink.com

\begin{abstract}
Purpose of Review Ogimi village is renowned for its aging population. We sought to determine if the L-serine content of their diet could account for their neurological health.

Recent Findings The most frequently consumed food items, including tofu and seaweeds, are rich in the dietary amino acid L-serine. L-serine content of the Ogimi diet $>8$ grams/day for Ogimi women significantly exceeds the average American dietary intake of 2.5 grams/day for women $>70$ years old. Summary Our hypothesis that the high L-serine content of the Ogimi diet is related to the paucity of tangle diseases among villagers is buttressed by in vivo results with non-human primates where dietary L-serine slowed development of neurofibrillary tangles and $\beta$-amyloid plaques by up to $85 \%$ and a human clinical trial finding that L-serine at 15 grams/day twice daily slows functional decline in ALS patients. Analysis of the Ogimi diet suggests that L-serine should be evaluated for therapeutic potential as a neuroprotective agent.
\end{abstract}

Keywords L-Serine - Dietary amino acids · Tangle diseases · Alzheimer's disease $\cdot$ ALS $\cdot$ Neuroprotection

This article is part of the Topical Collection on Neurological Disease and Cognitive Function

Paul Alan Cox

paul@ethnomedicine.org

James S. Metcalf

james@ethnomedicine.org

1 Brain Chemistry Labs, Institute for Ethnomedicine, Box 3464, Jackson, WY 83001, USA

\section{Introduction}

The population of Okinawa has achieved considerable fame for the overall longevity of its population, with Okinawan women having an average life expectancy of 85.08 years, exceeding the average Japanese women's life expectancy of 83.99 years $[1,2]$. Within Okinawa, the remote Ogimi village at the extreme north of the island has achieved the title of "longevity village" for its high number of centenarians. Despite considerable attention having been given to the Okinawan diet [3], there has not been an ethnobotanical survey performed for Ogimi village regarding dietary preferences.

Within the Okinawan political context, Ogimi village is a clear outlier due to its remoteness and its cultural isolation. Remarkably, the indigenous people in Ogimi have maintained their own language which is not understood by other Okinawans. Ogimi villagers learn Japanese in school, but maintain a distinct culture and religion.

The Ogimi diet has unique elements based on marine algae. Ogimi villagers who move to the Okinawan capital of Naha ask family members to supply them with those seaweeds. To explore a possible neuroprotective function for L-serine, we surveyed the Ogimi diet and analyzed the most frequently consumed items for L-serine content.

\section{L-Serine as a Potential Neuroprotective Agent}

L-Serine is abundant in human diets. The mean concentration in blood plasma is $0.12 \mathrm{mM}$ and is not reduced in elderly Okinawans [4], while in intracellular tissue the mean is $0.98 \mathrm{mM}$ [5]. L-Serine is produced within the central nervous system [6] and is essential for cell cultures and cell proliferation [7]. L-Serine, a precursor for L-glycine, is produced from 
3-phosphoglycerate. Transport of L-serine across the bloodbrain barrier is via the sodium-dependent system $\mathrm{A}$ and the sodium-independent alanine, serine, and cysteine preferring system (ASC) [8-10]. Made by astrocytes and neurons [11, 12], L-serine is a precursor to phosphoglycerols, sphingolipids, sulfur amino acids, and D-serine which serves as a cofactor at NMDA receptors. It is enzymatically degraded by serine dehydratase, with $\mathrm{NH}_{3}$ and pyruvate as the end nitrogen and carbon metabolites, respectively [13].

A deficiency in L-serine can trigger the genetic disease 3phosphoglycerate dehydrogenase deficiency and 3phosphoserine phosphatase deficiency [14]. L-Serine is currently in a phase I clinical trial as a treatment for hereditary sensory autonomic neuropathy type 1 [15].

Indications that L-serine may be neuroprotective came from studies of human neuronal cell culture in which protein aggregation and cell apoptosis was triggered by the cyanobacterial toxin $\beta$ - $N$-methylamino-L-alanine (BMAA) [16]. BMAA contaminated the diet of the Chamorro people of Guam [17]. Increasing L-serine in neuronal cell culture prevents BMAA misincorporation [18•].

Vervet monkeys with chronic dietary exposure to BMAA developed neurofibrillary tangles and plaques immunopositive for phosphotau and $\beta$-amyloid deposits consistent with Guam ALS/PDC [19••, 20]. Based on both in vitro and in vivo indications of a neuroprotective function for Lserine, an FDA-approved phase I clinical trial on 20 ALS patients was conducted. In addition to findings of safety, a statistically significant indication of efficacy was found: patients taking L-serine at 5 and $15 \mathrm{~g} /$ day had a $22 \%$ reduction in the rate of functional decline, while those at $30 \mathrm{~g} /$ day of Lserine experienced an $85 \%$ reduction in functional decline by the slope of ALSFRS-R [21••].In January 2017, the FDA approved a Phase IIa clinical trial (IND 133607) of L-serine for Alzheimer's patients.

Given both the longevity and the apparent paucity of progressive neurodegenerative disease among the Ogimi villagers, an ethnobotanical study was designed to determine the most frequently consumed components of the Ogimi diet and to test those components for L-serine content.

\section{Methods}

\section{Ethnobotanical Survey}

The diet of Ogimi village, with a focus on the most frequently consumed food items, was studied through ethnobotanical surveys of the aged villagers in six different week-long expeditions to the village. Using participant observation techniques [22], villagers were initially surveyed to develop a comprehensive list of the 25 most common or highly salient food items. Villagers collecting marine algae or terrestrial plants were photographed, and the manufacture of tofu from soy beans by villagers was documented, as was the manufacturer of flour from the gametophytes of Cycas revoluta (Cycadaceae) which contains BMAA [23]. Interviews were conducted in Japanese but plant and animal species were referred to by their Ogimi names. Photographs of these food items were printed on $8 \times 10$ cardstock, one photograph per sheet, with the Ogimi name written in Hiragana above the photograph. Fifty different villagers were shown each photograph and questioned as to their personal frequency of consumption and the amount they consumed. Median frequency of consumption was then calculated for each food item. Samples of each food item were analyzed for amino acid content.

\section{Extraction of Food Items}

Solid food items, obtained from Ogimi village, were placed into $50-\mathrm{ml}$ plastic Falcon tubes and frozen at $-80^{\circ} \mathrm{C}$. The sclerotesta from cycad seeds was removed and the gametophyte exposed before freezing in 50-ml Falcon tubes. After freeze-drying, subsamples were placed inside microcentrifuge tubes with the addition of 5-10 glass beads, then macerated using a bead beater (Omni bead beater 24, Omni International, Kennesaw, GA, USA) for 20-30 s. Once disrupted, a subsample was weighed into a 1.6- $\mathrm{ml}$ screw-capped glass vial. $6 \mathrm{M}$ $\mathrm{HCl}$ was added at a concentration of $50 \mathrm{mg} / \mathrm{ml}$. For liquid samples, $500 \mu \mathrm{l}$ was placed into a 1.6-ml screw-capped glass vial and an equal volume of $12 \mathrm{M} \mathrm{HCl}$ was added. Samples were then hydrolyzed at $110^{\circ} \mathrm{C}$ for $16 \mathrm{~h}$. Once cooled, $200 \mu \mathrm{l}$ of the hydrolysate were centrifuge filtered $(0.22 \mu \mathrm{m}$; Millipore Ultrafree-MC, Billicore, MA, USA) and dried in a SpeedVac. Once dried, the residue was stored at $-20^{\circ} \mathrm{C}$.

\section{Analysis of Collected Materials by Amino Acid Analyzer}

Dried residues were re-suspended with $200 \mu \mathrm{l}$ of $20 \mathrm{mM} \mathrm{HCl}$ and analyzed by amino acid analyzer (Hitachi 8900 ). Samples $(10 \mu \mathrm{l})$ of the re-suspended extract or a 1/10 dilution with $20 \mathrm{mM} \mathrm{HCl}$ were injected into a Hitachi Amino Acid Analyzer L8900 equipped with a Hitachi Reaction column (PN 855-3533) at $135{ }^{\circ} \mathrm{C}$, a high-speed physiological fluid analysis analytical column (Li-form resin \#2622SC $6 \mathrm{~mm}$ ID $\times 40$ L 060928C; PN855-4515), precolumn (PN8553643), guard column \#2619 $4 \mathrm{~mm}$ ID $\times 5$ L 2007.07.19 070639 (PN855-5268), and ammonia filter column (ion exchange $4.6 \times 40$ column \#2650 L, PN 855-3523). Pre-made buffers (Hitachi) were used as follows: (B1) PF-1/AN08711, (B2) PF-2/AN0-8712, (B3) PF-3/AN0-8713, (B4) PF4/AN0-8714, (B5) 5\% methanol, (B6) PF-RG/AN0-8715, (R1) ninhydrin solution, (R2) ninhydrin-buffer of lithium acetate dihydrate, (R3) 5\% ethanol. Separation was made with a flow rate for pump 1 of 0.53 and $0.45 \mathrm{ml} / \mathrm{min}$ for pump 2 and a 


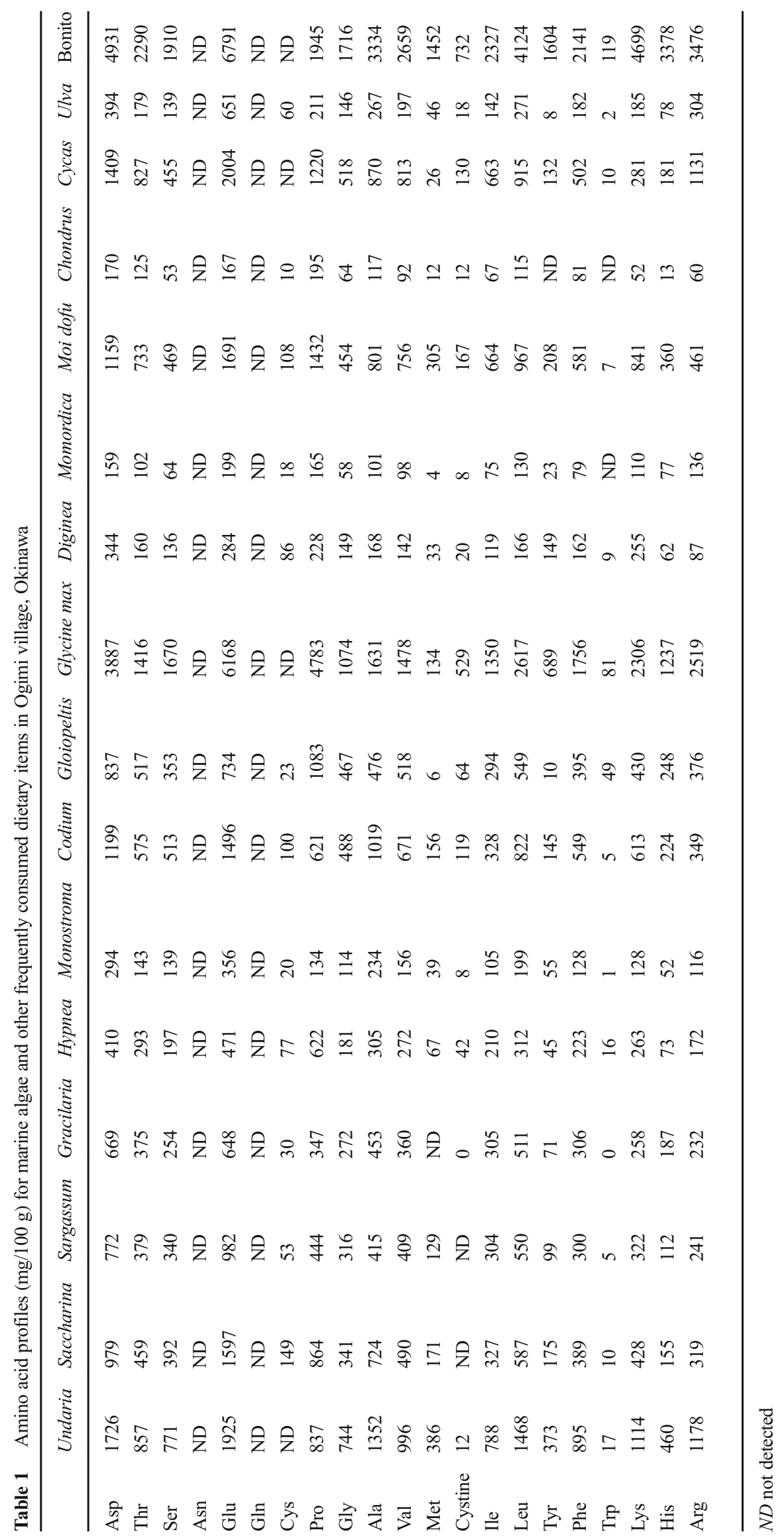


$152 \mathrm{~min}$ gradient elution $(0.0 \mathrm{~min}=100 \% \mathrm{~B} 1$, separation column and guard column temp $35{ }^{\circ} \mathrm{C}, 50 \% \mathrm{R} 1,50 \% \mathrm{R} 2$; $1.5 \mathrm{~min}=$ column $32{ }^{\circ} \mathrm{C} ; 15.6 \mathrm{~min}=81 \% \mathrm{~B} 1,19 \% \mathrm{~B} 2$, column $57{ }^{\circ} \mathrm{C} ; 36 \min =60{ }^{\circ} \mathrm{C} ; 45 \mathrm{~min}=32{ }^{\circ} \mathrm{C} ; 57 \mathrm{~min}=70{ }^{\circ} \mathrm{C}$; $68 \min =15 \%$ B1, $75 \%$ B2, $10 \%$ B3; $69 \min =58{ }^{\circ} \mathrm{C}$; $76.1 \mathrm{~min}=60 \% \mathrm{~B} 2,40 \% \mathrm{~B} 3 ; 89 \mathrm{~min}=65^{\circ} \mathrm{C} ; 95 \mathrm{~min}=20 \%$ $\mathrm{B} 2,80 \% \mathrm{~B} 4 ; 98.1 \mathrm{~min}=25 \% \mathrm{~B} 2,75 \% \mathrm{~B} 4 ; 112.1 \mathrm{~min}=100 \%$ $\mathrm{B} 4 ; 125 \mathrm{~min}=70{ }^{\circ} \mathrm{C} ; 125.1 \mathrm{~min}=100 \% \mathrm{R} 3$; $129.1 \mathrm{~min}=100 \% \mathrm{~B} 6 ; 132.1=100 \% \mathrm{~B} 1 ; 137.1 \mathrm{~min}=50 \%$ $\left.\mathrm{R} 1,50 \% \mathrm{R} 2,35^{\circ} \mathrm{C}\right)$.

Amino acid concentrations were determined from retention times of individual L-amino acid standards, corresponding to the 20 canonical amino acids (Sigma Chemical Co., St. Louis, MO). Using peak area and retention time, the amino acid concentrations were determined on a gravimetric basis for solid food samples and on a volumetric basis for liquid samples.

\section{Results}

The top 25 most frequently consumed food items are listed in Table 1. Since dried bonito (Katsuwonus pelamis) is used as a seasoning in many indigenous dishes, it was arbitrarily placed at rank 25 . It is notable that 13 species of marine algae occur in the top 25 most frequently consumed food items. Dietary preferences of the Ogimi diet showed only subtle variation between different ages of respondents. Comparing respondents between 50 and 79 years old with those 80 or older, older respondents ranked Ipomoea batatas, pork, and the marine algae Gloiopeltis tenax, Codium yezoense, and Chondrus ocealltus higher than did younger respondents.

Complete amino acid profiles of these frequently consumed items are shown in Table 2, with a representative chromatogram for the marine alga (Hypnea charoides, moi in the Ogimi language) cooked as moi dofu shown in Fig. 1. The Ogimi diet is remarkably rich in amino acids, including Lserine, with food items (excluding dried bonito) having a mean L-serine content of $542 \mathrm{mg} / 100 \mathrm{~g}$. However, it does not appear that L-serine content alone impacts the relative frequency of consumption. The two most frequently consumed food items, Citrus depressa fruits (kugani in the Ogimi language) and rice, are relatively low in L-serine content. Neither the Spearman's rank correlation coefficient for the L-serine content vs. rank of the top 25 preferred items $(r=0.15)$ nor for 13 taxa of marine algae in the top 25 items $(r=0.21)$ was significant at the 0.05 level. By weighing all
Table 2 Ranked frequency of consumption of the 25 top food items in the Ogimi diet compared to rank content $\mathrm{mg} / \mathrm{g}$ of $\mathrm{L}$-serine

\begin{tabular}{|c|c|c|c|c|c|}
\hline Overall rank & Item & Ogimi name & Median & SER rank & Serine $(\mathrm{mg} / 100 \mathrm{~g})$ \\
\hline 1 & Citrus depressa juice & Kugani & 1 & 15 & $162.7 *$ \\
\hline 2 & Oryza sativa & Gohan & 2 & 19 & 128.1 \\
\hline 3 & Momordica charantia & Goya & 5 & 21 & 64.0 \\
\hline 4 & Tofu & Tofu & 6 & 1 & 2351.5 \\
\hline 5 & Undaria pinnatifida & Wakame & 8 & 5 & 771.4 \\
\hline 6 & Saccharina japonica & Kombu & 9 & 10 & 391.5 \\
\hline 7 & Glycine $\max$ & Edamame & 9 & 3 & 1670.3 \\
\hline 8 & Ipomoea batatas & Beneimo & 10 & 8 & 480.0 \\
\hline 9 & Ulva lactuca & Aasa & 10 & 17 & 138.8 \\
\hline 10 & Artemisia princeps & Fuchiba & 12 & 4 & 805.3 \\
\hline 11 & Sargasssum fusiformis & Hijiki & 12 & 12 & 339.5 \\
\hline 12 & Pork & Samaniku & 12 & 2 & 1799.5 \\
\hline 13 & Gynura japonica & Handema & 12 & 6 & 649.3 \\
\hline 14 & Monostroma nitidum & Aasa & 13 & 16 & 138.9 \\
\hline 15 & Hypnea charoides & $M o i$ & 16 & 14 & 196.5 \\
\hline 16 & Gracilaria vermiculophylla & Sunna & 17 & 13 & 253.9 \\
\hline 17 & Cladosiphon okamuranus & Sunui & 17 & 20 & 74.1 \\
\hline 18 & Gloiopeltis tenax & Funui & 18 & 11 & 353.3 \\
\hline 19 & Chondrus ocealltus & Sinumata & 19 & 22 & 52.8 \\
\hline 20 & Codium yezoense & Biru & 20 & 7 & 512.5 \\
\hline 23 & Diginea simplex & Nachura & 21 & 18 & 135.9 \\
\hline 24 & Cycas revoluta & Sotetsu & 22 & 9 & 455.4 \\
\hline 25 & Katsuwonus pelamis & Kotsuo & Unranked & & \\
\hline
\end{tabular}

*mg/L 


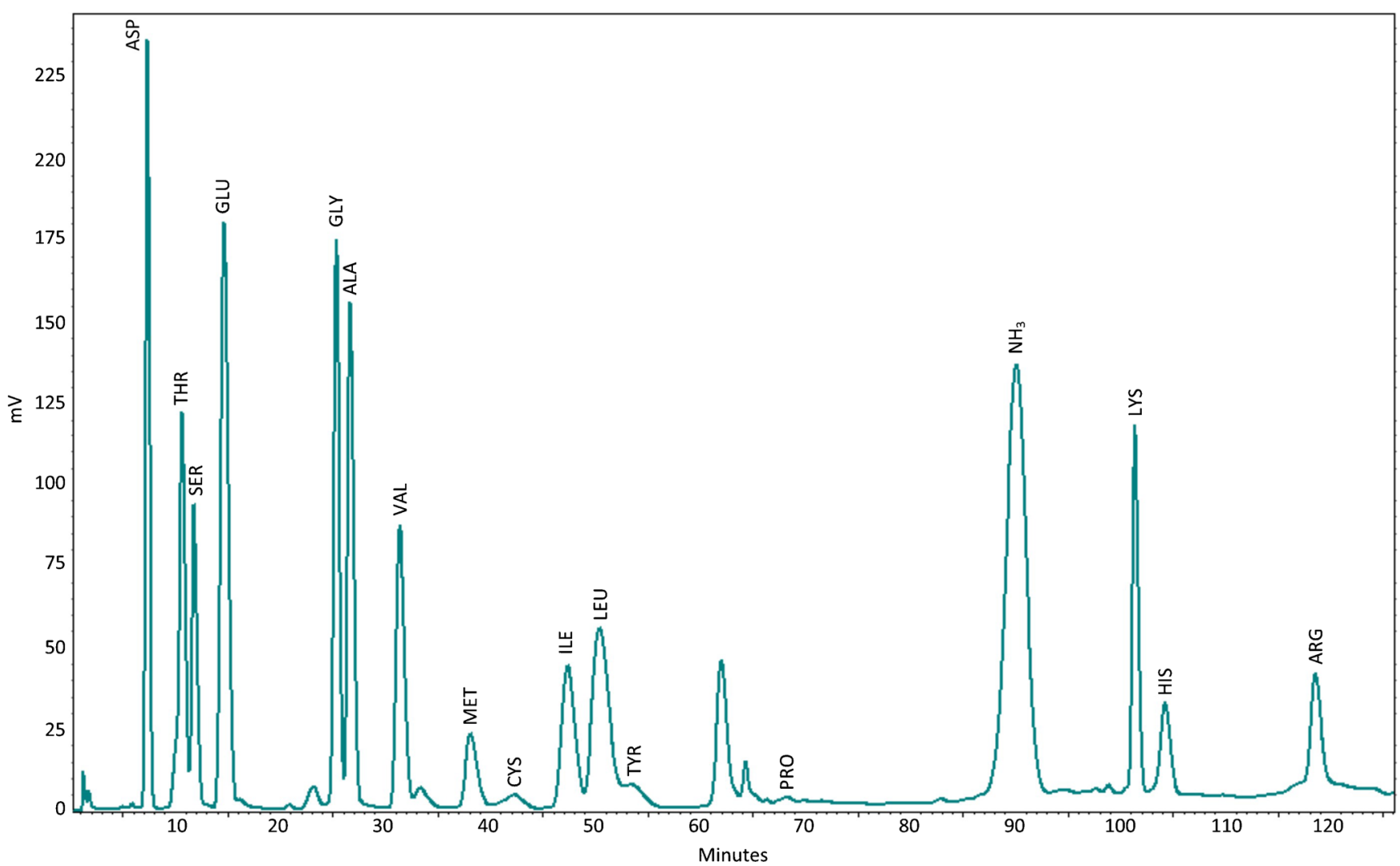

Fig. 1 Amino acid profile of the marine algae Hypnea charoides (Cystocloniaceae) which had been cooked as moi dofu for consumption in Ogimi village, Okinawa, as determined by amino acid analyzer

food items consumed in a single day by an Ogimi villager and calculating from Table 2 the L-serine equivalents, it appears that total L-serine content of the Ogimi diet for women over the age of 70 is in excess of $8 \mathrm{~g} /$ day. This is about $6 \mathrm{~g} /$ day above the daily L-serine intake ( $2.53 \mathrm{~g} /$ day) from all sources consumed by women in the USA and twice the L-serine intake ( $7.15 \mathrm{~g} /$ day) consumed by the 99th percentile of US women age $71+[24]$.

L-Serine-rich dietary items are consumed in religious festivals within Ogimi village, which occur several times a month. In the matriarchal society of Ogimi, women from the highlands bring $C$. depressa (kugani) fruits to these religious rituals, while coastal women bring marine algae. A meal is served consisting of tofu (23,510 $\mu \mathrm{g} / \mathrm{g}$ L-serine), Saccharina japonica (kombu), and H. charoides (moi) which is boiled and mixed with bonito flakes and carrots or other vegetables, producing a gelatin-like substance called in Ogimi moi dofu. The amino acid profile of moi dofu (Fig. 1) shows that it is rich in L-serine and other amino acids.

\section{Discussion}

Nutritional characteristics of food items consumed within Okinawa (Fig. 2) have received considerable attention over

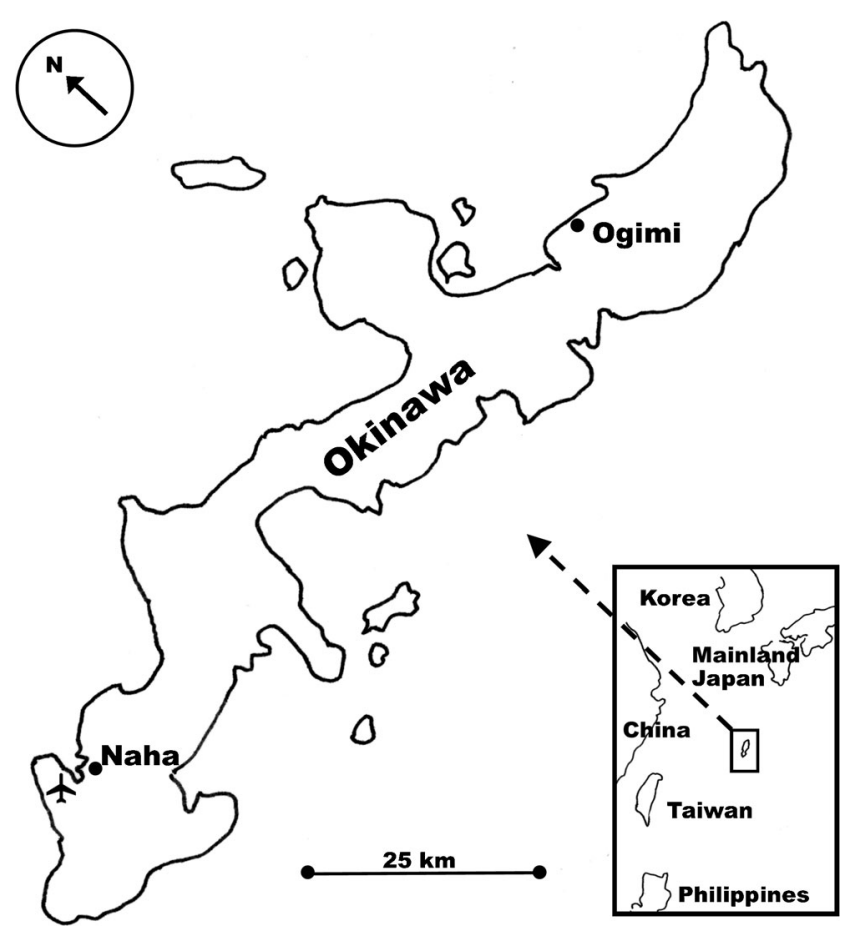

Fig. 2 While politically part of Japan, Okinawa is remote from the Japanese mainland. Within Okinawa, Ogimi village is geographically, linguistically, and culturally isolated 
the last decade. Emphasis has been placed on the abundance of antioxidants in the food items as well as the low-calorie and high glycemic index of traditional Okinawan food [25]. Perhaps because of recent discoveries on the impact of caloric restriction on longevity of laboratory animals [26], emphasis has been placed on anti-obesity aspects of the Okinawan diet $[2,25,27,28]$, based on the assumption that caloric restriction will reduce risks of atherosclerosis and diabetes in human populations [29]. Indeed, post-war Okinawans with a diet of approximately $11 \%$ less than the 1949 mean daily caloric intake of $1785 \mathrm{kcal} /$ day would have had a reduced body mass index (BMI)[2]. In our ethnobotanical surveys, Ogimi villagers often spoke of nutritional deprivation during and after World War II. The question is whether malnutrition of Okinawans during the war had a positive or deleterious impact [30]. However, as regards nutritional deprivation during war time, the Okinawans were not unique. Cox [31] in an analysis of height and weight measurements of nearly 600,000 German children in World War I found extensive indications of nutritional stress and highly reduced BMI as a result of chronic caloric deficits; however, there is no evidence of increased longevity among the German population, nor is there indication of increased longevity among other populations that have suffered caloric deficits as a result of war. We also note that in our ethnobotanical surveys, contemporary Ogimi villagers, while not obese, do not appear to have a significantly reduced BMI compared to other populations, and nothing approaching the $30-70 \%$ reduction in calories required in laboratory animals to increase longevity [32]. While not disputing the advantages of eating a plant-based diet, minimal tobacco use, and regular physical activity for a healthy lifestyle [33] which lower risks of cancer and type II diabetes [34], we suggest that a more careful consideration of the remarkable emphasis on soy products and marine algae in the Ogimi diet, particularly an analysis of the amino acid content of that diet, can give important clues as to the source of neurological health.

The importance of fermented soy products, in the form of tofu, and the frequency of consumption of Glycine max as edamame, which appear to be the major source of calories in the Ogimi diet (as opposed to rice in the rest of Japan), and particularly the importance and diversity of marine algae consumed by villagers, appear to distinguish the Ogimi diet. "The Okinawan people have always included a number of different varieties of seaweed in their everyday diet and in large amounts. Konbu [sic] is particularly used, which is not locally produced, nevertheless features in both traditional festival menus and in the everyday diet" ([35] pp. 163-164). The import of kombu (Saccharina japonica) from Hokkaido to Okinawa in general and Ogimi in particular stretches back nearly two centuries.

It is claimed that edible seaweeds in general, and kombu and wakame (Undaria pinnatifida) in particular, are good sources of protein $[36,37,38]$ and offer a complete complement of essential amino acids [39, 40]. Although seaweeds are particularly rich in glutamic acid, alanine, and phenylalanine [41], we here note they are also rich sources of L-serine. Hypnea charoides and Ulva lactuca have been found by previous investigators to be good sources of L-serine [42, 43]. Wakame may also serve to reduce serum and lower triacylglycerol [44], while the fruits of $C$. depressa, which is the most frequently consumed food item in Ogimi village, have clear hypolipidemic effects, which together with the antioxidants present in the fruit reduce the risk of lifestyle disease [45].

\section{Conclusions}

Food preferences and taboos embedded within indigenous religions are strong indicators of cultural importance [22, 46]. During frequent indigenous religious ceremonies in Ogimi, participants consume a meal which is extraordinarily high in L-serine. Although Ogimi villagers have not been aware either of the high amino acid content of their indigenous diet, nor of recent research suggesting that L-serine in particular has neuroprotective activity, both their religion and cultural practice ensure that they consistently receive one of the highest L-serine-containing diets in the world. The people of Ogimi are known to be long-lived. A wide range of potential factors could contribute to their longevity. Due to the unique nature of their diet, rich in seaweeds and tofu, the high serine content of their diet may offer neuroprotection and contribute to their neurological health in this community.

Acknowledgements We thank Brain Chemistry Labs Emeritus Director Mr. Masayuki Kishimoto and his brother Mr. Masaharu Kishimoto, both of whom were raised in Okinawa, and Mr. Chiba Koetsu for facilitating and funding our research in Okinawa. The Senior Citizen Coordinator for Ogimi village Mr. Miyagi scheduled our visits with Ogimi elders and assisted with translations from the Ogimi language. Mr. Susumu Onodera provided simultaneous Japanese translation and significant cultural advice. We thank the Mayor and Council of Ogimi village for permission to conduct our interviews and all of the 50 village elders who graciously agreed to interviews. Marilyn Asay assisted in the statistical analysis and manuscript preparation.

\section{Compliance with Ethical Standards}

Conflict of Interest The Institute for Ethnomedicine has applied for patents for the use of L-serine to treat neurodegenerative illness (US 13/ $683,821)$.

Human and Animal Rights and Informed Consent Other than interviews, this article does not contain any studies with human or animal subjects performed by any of the authors.

Open Access This article is distributed under the terms of the Creative Commons Attribution 4.0 International License (http://creativecommons. org/licenses/by/4.0/), which permits unrestricted use, distribution, and reproduction in any medium, provided you give appropriate credit to the original 
author(s) and the source, provide a link to the Creative Commons license, and indicate if changes were made.

\section{References}

Papers of particular interest, published recently, have been highlighted as:

- Of importance

-• Of major importance

1. Yamori Y, Miura A, Taira K. Implications from and for food cultures for cardiovascular diseases: Japanese food, particularly Okinawan diets. Asia Pac J Clin Nutr. 2001;10:144-5. doi:10. 1046/j.1440-6047.2001.00227.x.

2. Willcox BJ, Willcox DC, Todoriki H, Fujiyoshi A, Yano K, He Q, et al. Caloric restriction, the traditional Okinawan diet, and healthy aging. Ann N Y Acad Sci. 2007;1114:434-55. doi:10.1196/annals. 1396.037.

3. Willcox BJ, Willcox DC, Suzuki M. The Okinawa program: how the world's longest-lived people achieve everlasting health - and how you can too. New York: Clarkson Potter; 2001.

4. Chan YC, Suzuki M, Yamamoto S. A comparison of anthropometry, biochemical variables and plasma amino acids among centenarians, elderly and young subjects. J Am Coll Nutr. 1999;18:358-65. doi:10.1080/07315724.1999.10718876.

5. Bergström J, Fürst $P$, Noree LO, Vinnars E. Intracellular free amino acid concentration in human muscle tissue. J Appl Physiol. 1974;36:693-7.

6. Wolosker H, Radzishevsky I. The serine shuttle between glia and neurons: implications for neurotransmission and neurodegeneration. Biochem Soc Trans. 2013;41:1546-50. doi:10.1042/ BST20130220.

7. de Koning TJ, Snell K, Duran M, Berger R, Surtees R. L-Serine in disease and development. Biochem J. 2003;371:653-61. doi:10. 1042/bj20021785.

8. Tayarani I, Lefauconnier JM, Roux F, Bourre JM. Evidence for an alanine, serine, and cysteine system of transport in isolated brain capillaries. J Cereb Blood Flow Metab. 1987;7:585-91. doi:10. 1038/jcbfm.1987.109.

9. Yamamoto T, Nishizaki I, Furuya S, Hirabayashi Y, Takahashi K, Okuyama S, et al. Characterization of rapid and high-affinity uptake of L-serine in neurons and astrocytes in primary culture. FEBS Lett. 2003;548:69-73.

10. Hawkins RA, O'Kane RL, Simpson IA, Viña JR. Structure of the blood-brain barrier and its role in the transport of amino acids. J Nutr. 2006;136:218S-26S.

11. de Miranda J, Panizzutti R, Foltyn VN, Wolosker H. Cofactors of serine racemase that physiologically stimulate the synthesis of the N-methyl-D-aspartate (NMDA) receptor coagonist D-serine. Proc Natl Acad Sci. 2002;99:14542-7. doi:10.1073/pnas.222421299.

12. Wolosker H. NMDA receptor regulation by D-serine: new findings and perspectives. Mol Neurobiol. 2007;36:152-64. doi:10.1007/ s12035-007-0038-6.

13. Matthews DE. Proteins and amino acid. In: Ross AA, Caballero B, Cousins RJ, Tucker KL, Ziegler TR, editors. Modern nutrition in health and disease. 11th ed. Philadelphia: Walter Kluwer/Lippincott Williams \& Wilkins; 2014.

14. de Koning TJ. Treatment with amino acids in serine deficiency disorders. J Inherit Metab Dis. 2006;29:347-51. doi:10.1007/ s10545-006-0269-0.

15. Garofalo K, Penno A, Schmidt BP, Lee HJ, Frosch MP, von Eckardstein A, et al. Oral L-serine supplementation reduces production of neurotoxic deoxysphingolipids in mice and humans with hereditary sensory autonomic neuropathy type 1 . J Clin Invest. 2011;121:4735-45. doi:10.1172/JCI57549.

16. Cox PA, Banack SA, Murch SJ. Biomagnification of cyanobacterial neurotoxins and neurodegenerative disease among the Chamorro people of Guam. Proc Natl Acad Sci U S A. 2003;100:13380-3. doi:10.1073/pnas.2235808100.

17. Banack SA, Murch SJ, Cox PA. Neurotoxic flying foxes as dietary items for the Chamorro people, Marianas Islands. J Ethnopharmacol. 2006;106:97-104. doi:10.1016/j.jep.2005.12. 032.

18. Dunlop RA, Cox PA, Banack SA, Rodgers KJ. The non-protein amino acid BMAA is misincorporated into human proteins in place of L-serine causing protein misfolding and aggregation. PLoS One. 2013;8:e75376. doi:10.1371/journal.pone.0075376. This paper demonstrates that increasing $\mathrm{L}$-serine content in vitro reduces protein aggregation and apoptosis in human neuronal cell culture.

19.• Cox PA, Davis DA, Mash DC, Metcalf JS, Banack SA. Dietary exposure to an environmental toxin triggers neurofibrillary tangles and amyloid deposits in the brain. Proc R Soc B. 2016;283: 20152397. doi:10.1098/rspb.2015.2397. L-Serine is shown to reduce density of brain tangles by $50-80 \%$ in nonhuman primates.

20. Cox PA, Sacks OW. Cycad neurotoxins, consumption of flying foxes, and ALS-PDC disease in Guam. Neurology. 2002;58:9569. doi:10.1212/WNL.58.6.956.

21.• Levine TD, Miller RG, Bradley WG, Moore DH, Saperstein DS, Flynn LE, et al. Phase I clinical trial of safety of L-serine for ALS patients. Amyotroph Lateral Scler. 2016;25:1-5. doi:10.1080/ 21678421.2016.1221971. L-Serine supplementation slows functional decline of ALS patients.

22. Balick MJ, Cox PA. Plants, people, and culture: the science of ethnobotany. New York: Scientific American Library; 1996.

23. Banack SA, Cox PA. Distribution of the neurotoxic nonprotein amino acid BMAA in Cycas micronesica Hill. Bot J Linn Soc. 2003;143:165-8. doi:10.1046/j.1095-8339.2003.00217.x.

24. Institute of Medicine (US). Panel on Micronutrients. Dietary reference intakes for energy, carbohydrate, fiber, fat, fatty acids, cholesterol, protein and amino acids. Panel on Macronutrients Panel on the Definition of Dietary Fiber, Subcommittee on Upper Reference Levels of Nutrients, Subcommittee on Interpretation and Uses of Dietary Reference Intakes, and the Standing Committee on the Scientific Evaluation of Dietary Reference Intakes, Food and Nutrition Board. National Academies Press, 2005.

25. Willcox DC, Willcox BJ, Todoriki H, Suzuki M. The Okinawan diet: health implications of a low-calorie, nutrient-dense, antioxidant-rich dietary pattern low in glycemic load. J Am Coll Nutr. 2009;28:500S-16S. doi:10.1080/07315724.2009.10718117.

26. Weindruch R, Walford RL. Dietary restriction in mice beginning at 1 year of age: effect on life-span and spontaneous cancer incidence. Science. 1982;215:1415-8. doi:10.1126/science.7063854.

27. Niwano Y, Beppu F, Shimada T, Kyan R, Yasura K, Tamaki M, et al. Extensive screening for plant foodstuffs in Okinawa, Japan with anti-obese activity on adipocytes in vitro. Plant Foods Hum Nutr. 2009;64:6-10. doi:10.1007/s11130-008-0102-z.

28. Willcox DC, Willcox BJ, Todoriki H, Curb JD, Suzuki M. Caloric restriction and human longevity: what can we learn from the Okinawans? Biogerontology. 2006;7:173-7. doi:10.1007/s10522006-9008-z.

29. Holloszy JO, Fontana L. Caloric restriction in humans. Exp Gerontol. 2007;42:709-12. doi:10.1016/j.exger.2007.03.009.

30. Le Bourg É. Dietary restriction studies in humans: focusing on obesity, forgetting longevity. Gerontology. 2011;58:126-8. doi:10. $1159 / 000328675$. 
31. Cox ME. Hunger games: or how the Allied blockade in the First World War deprived German children of nutrition, and Allied food aid subsequently saved them. Econ Hist Rev. 2015;68:600-31. doi: 10.1111/ehr.12070.

32. Weindruch R. Caloric restriction and longevity. In: Biomedical advances in aging. US: Springer; 1990.

33. Suzuki M, Wilcox BJ, Wilcox CD. Implications from and for food cultures for cardiovascular disease: longevity. Asia Pac J Clin Nutr. 2001;10:165-71. doi:10.1111/j.1440-6047.2001.00219.x.

34. Takasu N, Yogi H, Takara M, Higa M, Kouki T, Ohshiro Y, et al. Influence of motorization and supermarket-proliferation on the prevalence of type 2 diabetes in the inhabitants of a small town on Okinawa, Japan. Intern Med. 2007;46:1899-904. doi:10.2169/ internalmedicine.46.0387.

35. Sho H. History and characteristics of Okinawan longevity food. Asia Pac J Clin Nutr. 2001;10:159-64. doi:10.1111/j.1440-6047. 2001.00235.x.

36. Barbarino E, Lourenço SO. An evaluation of methods for extraction and quantification of protein from marine macro-and microalgae. J Appl Phycol. 2005;17:447-60. doi:10.1007/s10811-005-1641-4.

37. Lourenço SO, Barbarino E, De-Paula JC, Pereira LO, Marquez UM. Amino acid composition, protein content and calculation of nitrogen-to-protein conversion factors for 19 tropical seaweeds. Phycological Res. 2002;50:233-41. doi:10.1111/j.1440-1835. 2002.tb00156.x.

38. Bocanegra A, Bastida S, Benedi J, Rodenas S, Sánchez-Muniz FJ. Characteristics and nutritional and cardiovascular-health properties of seaweeds. J Med Food. 2009;12:236-58. doi:10.1089/jmf.2008. 0151.
39. Dawczynski C, Schubert R, Jahreis G. Amino acids, fatty acids, and dietary fibre in edible seaweed products. Food Chem. 2007;103: 891-9. doi:10.1016/j.foodchem.2006.09.041.

40. Kolb N, Vallorani L, Milanovic N, Stocchi V. Evaluation of marine algae wakame (Undaria pinnatifida) and kombu (Laminaria digitata japonica) as food supplements. Food Technol Biotechnol. 2004;42:57-62.

41. Sánchez-Machado DI, López-Cervantes J, López-Hernández J, Paseiro-Losada P, Simal-Lozano J. High-performance liquid chromatographic analysis of amino acids in edible seaweeds after derivatization with phenyl isothiocyanate. Chromatographia. 2003;58:159-63.

42. Wong KH, Cheung PC. Nutritional evaluation of some subtropical red and green seaweeds: part I-proximate composition, amino acid profiles and some physico-chemical properties. Food Chem. 2000;71:475-82. doi:10.1016/S0308-8146(00)00175-8.

43. Wong KH, Cheung PC. Nutritional evaluation of some subtropical red and green seaweeds: part II-In vitro protein digestibility and amino acid profiles of protein concentrates. Food Chem. 2001;72: 11-7. doi:10.1016/S0308-8146(00)00176-X.

44. Murata M, Nakazoe JI. Production and use of marine algae in Japan. Jpn Agric Res Q. 2001;35:281-90.

45. Beppu F, Niwano Y, Kyan R, Yasura K, Tamaki M, Nishino M, et al. Hypolipidemic effects of ethanol extracts of Citrus depressa and Annona atemoya, typical plant foodstuffs in Okinawa, Japan on KKAy mice fed with moderately high fat diet. Food Sci Technol Res. 2009;15:553-6. doi:10.3136/fstr.15.553.

46. Monson CS, Cox PA. Prestige, taboo, and sustainability: predicting wildlife population trajectories in indigenous commerce. Pac Conserv Biol. 2007;13:4-13. doi:10.1071/pc070004. 